\title{
Reproductive and morphometric traits of Macrobrachium amazonicum (Decapoda: Palaemonidae) from the Pantanal, Brazil, suggests initial speciation
}

\author{
Liliam Hayd ${ }^{1,2} \&$ Klaus Anger ${ }^{2,3}$ \\ 1. Universidade Estadual de Mato Grosso do Sul, Campus de Aquidauana, 79200-000, Aquidauana, MS, Brazil; \\ lilihayd@yahoo.com.br \\ 2. The Pantanal Research Center. R. nove, 305. B. Boa Esperança, 78.068-410 - Cuiabá-MT, Brazil. \\ 3. Biologische Anstalt Helgoland, Alfred-Wegener-Institut für Polar- und Meeresforschung, Meeresstation, D-27498 \\ Helgoland, Germany; Klaus.Anger@AWI.de \\ 3. Corresponding author
}

Received 01-XII-2011. C Corrected 29-VIII-2012. Accepted 30-VIII-2012.

\begin{abstract}
The palaemonid shrimp Macrobrachium amazonicum shows an unusually large geographic range (ca. $4000 \mathrm{~km}$ across) living in coastal, estuarine, and limnic inland habitats of the upper Amazon, Orinoco, and La Plata basins. This raises doubts whether allopatric, ecologically diverse populations belong to the same species. While shrimps from estuarine and Amazonian habitats have been studied in great detail, very little is known about hololimnetic inland populations. In the present study, biological traits related to growth (maximum body size, fresh weight, morphometric relationships) and reproduction (sex ratio; occurrence of male morphotypes; minimum sexable size; minimum size of ovigerous females; fecundity; egg size), were studied in M. amazonicum collected from a pond culture and two natural freshwater habitats (Rio Miranda; Lagoa Baiazinha) in the Pantanal of Mato Grosso do Sul, Brazil. In total, 2270 shrimps were examined (603 males; 1667 females, 157 of these ovigerous). Sex ratio (males:females) was at all sampling sites strongly female-biased, ranging from 0.2-0.6. Maximum body size was larger in natural habitats compared to the pond culture, suggesting reduced growth or a shorter life span under artificial mass rearing conditions. Maximum fecundity observed in our material was 676 eggs, reached by the largest female ( $T L=65 \mathrm{~mm}$; Lagoa Baiazinha). A significant difference between slope parameters of linear regressions describing fecundity, either in terms of numbers of eggs laid or of larvae released, in relation to female fresh weight, indicates egg losses. This may be due in part to a 2.4 -fold increase in egg volume occurring during the course of embryonic development, while the available space under the abdomen remains limited. Size-weight relationships differed significantly between males and females, indicating sexspecific morphometric differences. Males appear to have a more slender body shape than females, reaching thus lower weight at equal TL. When reproductive and morphometric traits are compared with literature data from estuarine and inland populations living in the Amazon and Orinoco plains, shrimps from the Pantanal show conspicuous peculiarities differing from other populations: (1) maximum body size is far smaller, suggesting shorter longevity; (2) females are consistently larger than males; (3) different male morphotypes are absent; (4) minimum sexable size and (5) minimum size of ovigerous females are smaller. These traits suggest a heterochronic shift (predisplacement) of sexual maturation and r-selection. In summary, our data show biologically relevant differences in life-history traits of shrimps from the Pantanal compared to M. amazonicum populations in other regions. All these differences persist also in long-term cultures maintained under constant conditions. Altogether, our data support the hypothesis that M. amazonicum in the Paraná-Paraguay drainage basin has phylogenetically diverged from allopatric populations that are hydrologically separated by continental watersheds, implying an at least incipient vicariant speciation. Rev. Biol. Trop. 61 (1): 39-57. Epub 2013 March 01.
\end{abstract}

Key words: Caridea, freshwater shrimp, growth, reproduction, fecundity, life history. 
In the evolution of the caridean shrimps, the Palaemonidae and, in particular, clades belonging to the palaemonid genus Macrobrachium have been highly successful invaders in brackish and freshwater ecosystems (Jalihal et al. 1993, Freire et al. 2003, Bauer 2004). Among the currently recognised ca. 240 species of Macrobrachium, at least 57 live in the neotropical region, and new species are still being discovered, especially in land-locked freshwater habitats such as continental rivers, lakes, and subterranean caves (de Grave et al. 2009, de Grave \& Fransen 2011, Mejía-Ortíz \& López-Mejía 2011).

One of the most widely distributed monophyletic clades within this neotropical group of shrimps is currently assigned a single species, M. amazonicum (Heller 1862) (see Pileggi \& Mantelatto 2010, Vergamini et al. 2011). According to the taxonomic and biogeographic literature (e.g. Holthuis 1952; for recent review see Maciel \& Valenti 2009), this species has been recorded from a geographic area about $4000 \mathrm{~km}$ across, ranging from the Northern coasts of South America (Venezuela, Columbia, Guayana) to Northern Argentina and Paraguay, and from the foothills of the Andes (Ecuador, Peru, Bolivia) to the Atlantic coasts of Northeastern Brazil. This vast area of distribution comprises the estuarine reaches of coastal rivers draining to the Caribbean and Atlantic Ocean as well as fully limnic inland waters of the Orinoco, Amazon, São Francisco, and La Plata basins, which are hydrologically separated from each other by continental watersheds (Albert et al. 2011).

While adult morphology (Holthuis 1952) as well as recently published data of molecular genetics (Pileggi \& Mantelatto 2010, Vergamini et al. 2011) support the unity of this species, there is increasing evidence from studies of larval biology (Anger \& Hayd 2009, Anger et al. 2009, Anger \& Hayd 2010, Urzúa \& Anger 2011) and of the ontogeny of physiological functions (Charmantier \& Anger 2011), which suggests that at least the populations living in the La Plata (Paraná-Paraguay) basin must have phylogenetically separated from the remaining clades assigned to $M$. amazonicum. Earlier studies of molecular genetic diversity (Bastos 2002), extensive morphometric analyses (Porto 2004), as well as consistent differences in larval morphology and developmental patterns (K. Anger unpublished) corroborate the hypothesis of an at least incipient speciation.

This controversial discussion raises the question whether $M$. amazonicum living in the upper La Plata basin differs also in other life-history traits from tentatively conspecific populations in other hydrogeographic regions of South America. Such comparisons, however, are still severely hampered by poor availability of life-history data from the Paraná-Paraguay river system, which is hydrologically separated from the Amazon and São Francisco basins in the North (Buckup 2011, Carvalho \& Albert 2011). The present study therefore provides preliminary data for a population living in the Pantanal of Mato Grosso do Sul, Brazil, comparing patterns of growth and reproduction with previously reported data from other populations of M. amazonicum.

\section{MATERIALS AND METHODS}

The Pantanal, brief characterization of the study region: The Pantanal is the world's largest wetland, covering ca. $365000 \mathrm{~km}^{2}$, $140000 \mathrm{~km}^{2}$ of which comprise the central floodplains in Brazil, Bolivia, and Paraguay (Swarts 2000, Iriondo et al. 2007). According to the standard Köppen-Geiger climate classification system, this region is characterized as a sub-humid tropical savannah (AW category; Köppen 1936, Peel et al. 2007), with an average rainfall of $1100 \mathrm{~mm}$ per year and an annual average temperature of $26^{\circ} \mathrm{C}$. Physical, chemical, biological, and other environmental conditions in the Pantanal plain have in detail been described in various books and reviews, in particular the seasonal patterns of flood pulses and dry periods that are typical of this region (Heckman 1998, Willink et al. 2000, Junk et al. 2011a, Junk et al. 2011b, Nunes da Cunha \& Junk 2011a). 
Sampling sites, collection of shrimps: During the dry season (July-November) in 2008 and 2009, shrimps were collected from two natural freshwater habitats located in the Pantanal of Miranda, State of Mato Grosso do Sul (MS), Brazil (Fig. 1): (1) Miranda River (2009' S - 56 $30^{\circ} \mathrm{W}$ ); (2) Lagoa Baiazinha $\left(20^{\circ} 16^{\prime} \mathrm{S}-56^{\circ} 23^{\prime} \mathrm{W}\right)$, an adjacent shallow lake hydrologically connected to the river. Additional material was obtained from an artificial pond culture maintained at the State University (UEMS) at Aquidauana, MS $\left(20^{\circ} 28^{\prime}\right.$ S - $\left.55^{\circ} 48^{\prime} \mathrm{W}\right)$.

At all sampling sites, shrimps were collected from shallow habitats $(<1 \mathrm{~m}$ depth) near the water margins, mostly near floating mats of water hyacinth (Eichhornia spp.), using hand nets ( $70 \mathrm{~cm}$ diameter; $2 \mathrm{~mm}$ mesh size). Shrimps (in total 2270 individuals) were subsequently fixed and stored in labeled plastic containers with $70 \%$ ethanol. On sampling days, measurements of water temperature, $\mathrm{pH}$ and conductivity were carried out using a digital YSI 63 (Yellow Spring Instruments, USA) apparatus, those of dissolved oxygen concentration with an HI-9146 (Hanna, Germany) probe. Since we do not attempt to show here small-scale local or seasonal differences in environmental conditions, only minimum and maximum values of these parameters are given (Table 1) to briefly characterize the habitats from which our material was sampled.

The Miranda River (or Rio Miranda) is characterized by moderate to strong currents, entangled side branches, transitorily exposed sand banks, and floating mats of aquatic plants (Eichhornia azurea, E. crassipes, Alchornea castaneifolia), while fallen trees and overreaching riparian vegetation provide local shelter and some shade near the river banks (for

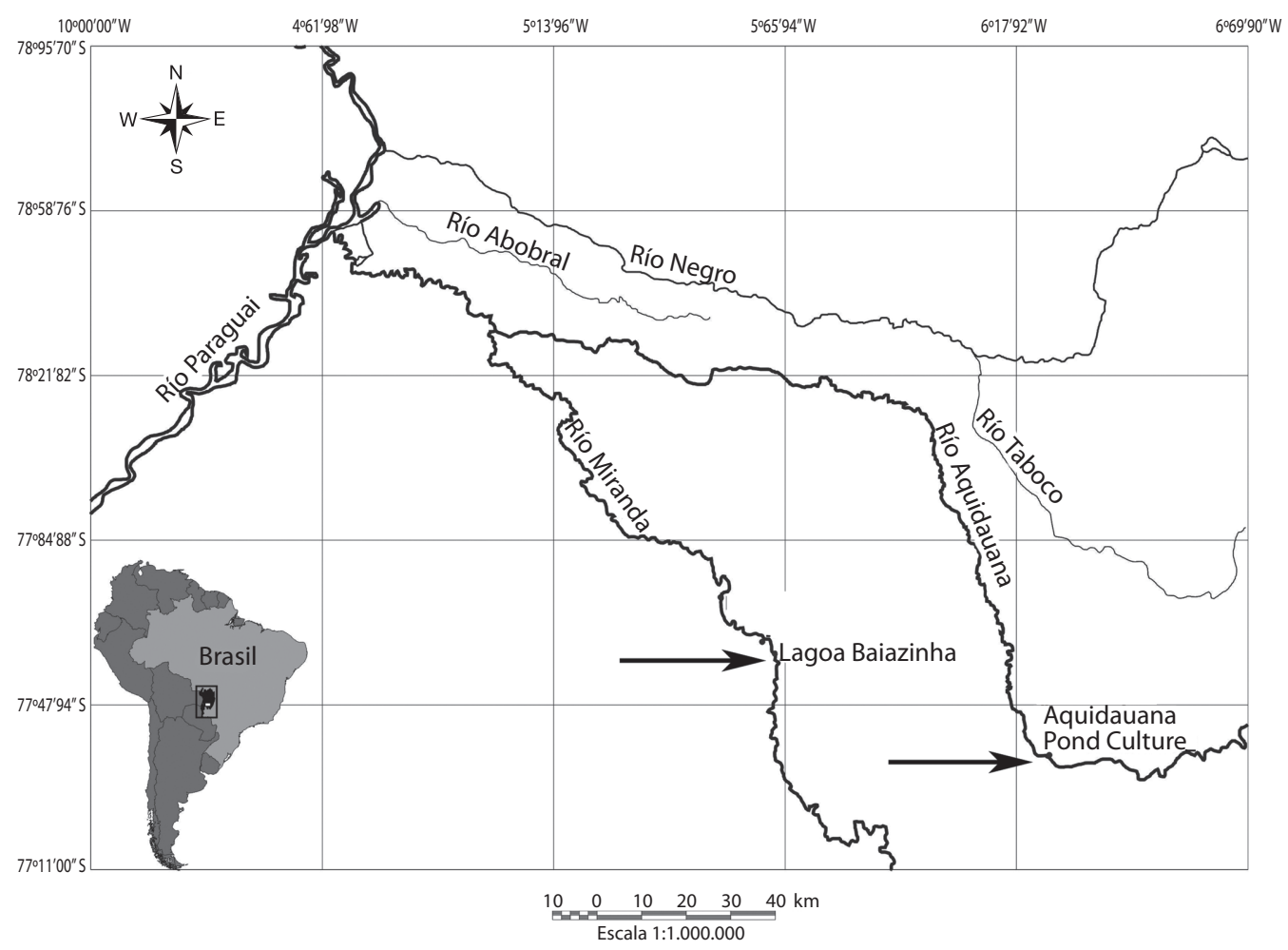

Fig. 1. Study area (with UTM coordinates) in the Pantanal of Mato Grosso do Sul, Brazil; locations of sampling sites on the Miranda River, nearby Lagoa Baiazinha, and artificial pond culture at the State University (UEMS) at Aquidauana marked with arrows. 
TABLE 1

Number of shrimps (empty and ovigerous females; total number of females and males; grand total for each site, $\Sigma$ ) collected from two natural freshwater habitats in the Pantanal of Mato Grosso do Sul, MS, Brazil, and from one artificial pond culture (State University of MS at Aquidauana)

\begin{tabular}{lcccc} 
& Rio Miranda & Lagoa Baiazinha & Pond culture & Total \\
Females & 779 & 323 & 565 & 1667 \\
(empty) & $(762)$ & $(278)$ & $(470)$ & $(1510)$ \\
(ovigerous) & $(17)$ & $(45)$ & $(95)$ & $(157)$ \\
Males & 289 & 191 & 123 & 603 \\
$\sum$ shrimps & 1068 & 514 & 688 & 2270 \\
$\mathrm{~T}\left({ }^{\circ} \mathrm{C}\right)$ & $17-30$ & $25-31$ & $20-31$ & \\
Cond $(\mu \mathrm{S} / \mathrm{cm})$ & $10-51$ & $26-43$ & $15-50$ & \\
$\mathrm{pH}$ & $7.0-8.2$ & $4.9-7.9$ & $5.7-8.4$ & \\
$\mathrm{DO}(\mathrm{mg} / \mathrm{l})$ & $7.0-8.3$ & $3.7-5.9$ & $4.2-7.7$ & \\
\hline
\end{tabular}

Minimum and maximum values of temperature ( $\mathrm{T}$ ), conductivity (Cond), $\mathrm{pH}$, and dissolved oxygen (DO) measured during the study period.

further ecological characterization of the Rio Miranda, see Depaula et al. 1995, Resende et al. 2000, Hayd \& Nakagaki 2002, Mendes et al. 2004, Resende et al. 2006, Pivari et al. 2008, Soares \& Oliveira 2009). Lake (or Lagoa) Baiazinha is connected, and thus, hydrologically similar to the Rio Miranda, but with almost stagnant water and denser mats of floating water hyacinth (for hydrological and ecological characteristics of shallow Pantanal lakes, see Heckman 1998, Willink et al. 2000, Suarez et al. 2004, Wantzen et al. 2008, Tondato et al. 2010).

The shrimps kept for aquaculture research at the UEMS in Aquidauana originated from the Rio Miranda (same site as above). This culture is maintained in an earthen pond $\left(300 \mathrm{~m}^{2} ; 1.5\right.$ depth) with flow-through conditions, receiving freshwater from a well (flow rate ca. 600L/min). Its surface is partially covered with floating mats of Eichhornia crassipes, whose roots provide shelter for shrimps. These are fed twice daily with commercial feeds for carnivorous fish (Mar $\&$ Terra and Douramix), offering an equivalent of about $3.5 \%$ of shrimp biomass per day (for details and references on cultivation techniques, see Moraes-Valenti \& Valenti 2010).

Examination of shrimps, eggs and larvae; and statistical analyses: In the laboratory, shrimps were identified using keys and further morphological information available for neotropical Macrobrachium (Holthuis 1952, Gomes Corrêa 1977, Kensley \& Walker 1982, Melo 2003). Some specimens were also sent to Dr. Célio Magalhães (Instituto Nacional de Pesquisas da Amazônia in Manaus, Brazil), who checked and confirmed previous identifications. Shrimps identified as M. amazonicum were counted and sexed (Ismael \& New 2000, Brown et al. 2010). As the smallest recognizable males (with appendix masculina expressed on the second pair of pleopods) had a total body length of $19 \mathrm{~mm}$, shrimps with smaller body size were regarded as immature juveniles, which were not considered in this study. The total numbers of shrimps that were collected from the different sampling sites and later used in this study (classified as males, nonovigerous females, or ovigerous females) are given in table 1.

Total length (TL, distance between the anterior margin of the rostrum and the distal tip of the telson) and carapace length (CL, posterior margin of the eye orbit to the midpoint of the posterior carapace margin) were measured to the nearest $0.01 \mathrm{~mm}$ under a dissecting microscope (Labor SE2200) equipped with a digital vernier caliper (Digimess 100.174BK Plus). Shrimps with broken rostrum or telson 
were disregarded. After brief blotting on filter paper, shrimp fresh weight (FW) was determined to the nearest $0.1 \mathrm{mg}$ on a Toledo (Ohays Adventurer AR2140) balance.

Male shrimps were checked for the presence of different morphotypes (Moraes-Riodades \& Valenti 2004). The sex ratio was calculated as number of males divided by the number of females (cf. Castillo et al. 2011). In ovigerous females, eggs were removed and counted under a dissecting microscope. Fecundity (number of eggs per female) was described in relation to TL, CL and FW (see below). A sample of 12 eggs per female was inspected under a compound microscope to measure egg size and classify the stage of embryonic development (Anger \& Moreira 1998, Ituarte et al. 2005). Three developmental stages were distinguished: (I) almost $100 \%$ of the egg volume occupied by yolk, no eye pigments visible, embryo showing little or no differentiation; (II) incipient eye formation visible as a reddish line, beginning embryonic differentiation (segmentation, development of appendices), heart beat visible but often irregular, yolk occupying ca $50-60 \%$ of egg volume; (III) eye fully developed, heart beat regular, differentiation of appendages in the final phase, yolk largely depleted. Egg volume (V) was calculated using the formula for an ellipsoid, $\mathbf{V}=\pi \cdot \mathbf{l} \cdot \mathbf{h}^{2} / \mathbf{6}$, where $\mathrm{l}=$ longest diameter (length) and $\mathrm{h}=$ shortest diameter (height).

In addition to the analysis of sampled and fixed materials (Table 1), 76 ovigerous females with eggs in a late developmental stage (III) were collected from the pond culture, and individually transferred to aquaria with freshwater $\left(2 \mathrm{~L}\right.$ volume; aeration; ca $30^{\circ} \mathrm{C}$; natural light conditions). Larvae hatching within five days were counted under a stereo microscope in order to detect possible differences between the initial egg number ("realised fecundity") and the number of larvae that eventually were released by females with a given body size; differences were considered as an indication of egg losses occurring during the time of embryogenesis (Anger \& Moreira 1998, Briggs et al. 2002, Ituarte et al. 2007). Fecundity, in terms of either egg or larval numbers per female, could be described as a linear function of female $\mathrm{FW}, \mathbf{F e c}=\mathbf{a}+\mathbf{b} \cdot \mathrm{FW}$, or as a power function of size dimensions $(\mathrm{x}=\mathrm{CL}$ or $\mathrm{TL}$ ), $\mathbf{F e c}=\mathbf{a}+\mathbf{x}^{\mathbf{b}}$. Slope parameters (b) were statistically compared with ANCOVA (Sokal \& Rohlf 1995).

Morphometric relationships between CL and TL were described separately for females (regardless whether ovigerous or non-ovigerous) and males, applying linear regression, $\mathbf{T L}=\mathbf{a}+\mathbf{b} \cdot \mathbf{C L}$ (Fig. 2). Non-linear models were also tested, but the coefficients of determination $\left(\mathrm{r}^{2}\right)$ were consistently lower. Again, the slope parameters (b) obtained for males and females, respectively, were compared with ANCOVA.

For all three categories of shrimp distinguished in this study (males, females with and without eggs; Table 1), relationships between TL and FW (in ovigerous females including the egg mass) were described using power functions, $\mathbf{F W}=\mathbf{a} \cdot \mathrm{TL}^{\mathbf{b}}$ (Hartnoll 1982). This analysis was initially carried out separately for each sampling site to test for possible differences in size-biomass relationships due to local variations in nutritional or other ecological conditions. However, when the slope (b) and intercept parameters (a) of the linearized power functions (after log-log transformation of data sets; for review of biometric functions describing fecundity, see Somers 1991) were compared by means of ANCOVA, no significant differences were detected among sampling sites. Consequently, the data from each sampling site were subsequently pooled for each category of shrimp, so that generalized sizeweight relationships could be given, and slopes of allometric functions could be statistically compared between shrimp categories using ANCOVA (for results, see Fig. 3D).

\section{RESULTS}

Habitat conditions: This study concentrated on life-history traits in a little known shrimp population from the Pantanal, which is currently assigned to the widely distributed species $M$. amazonicum. Therefore, only 



Fig. 2. Linear regressions describing the relationships between carapace length (CL) and total length (TL) of female (A) and male (B) Macrobrachium amazonicum from the Pantanal (pooled data from three sampling sites); $\mathrm{r}^{2}$, coefficient of determination; n, number of observations; F statistic and level of significance, P, for statistical comparison between slopes (ANCOVA; graph $\mathbf{C}$ ) indicate a highly significant morphometric difference between males and females. 

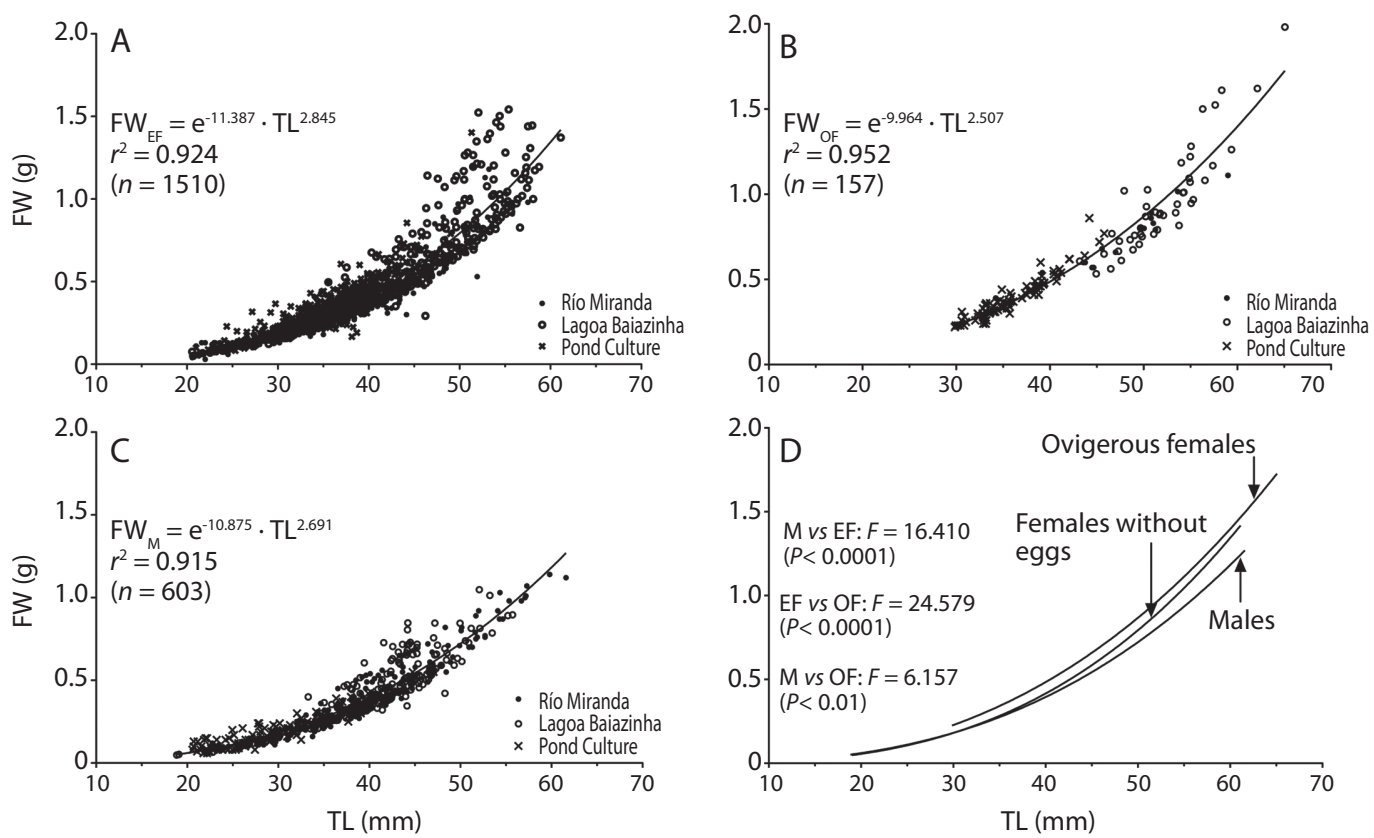

Fig. 3. Power functions describing the relationships between total length (TL) and fresh weight (FW) in non-ovigerous (or empty) females (EF; graph A), ovigerous females (OF; graph B), and males (M; graph C) of Macrobrachium amazonicum from the Pantanal (pooled data from three sampling sites); $r^{2}$, coefficient of determination; $n$, number of observations; $F$ statistics and levels of significance, $\mathrm{P}$, for statistical comparisons between slopes (ANCOVA, with log-transformed data sets; graph D) indicate significantly different size-weight relationships in males, non-ovigerous females, and ovigerous females.

a brief summary of preliminary data characterizing the environmental conditions at three different sampling sites is given here, and no attempts are made to compare in detail ecological or seasonal variations in small-scale local populations. While the maximum temperatures observed on collection days were similar (30$31^{\circ} \mathrm{C}$; Table 1 ), minimum values varied more strongly among sites $\left(17-25^{\circ} \mathrm{C}\right)$, with lowest variability at Lake Baiazinha. Likewise, maximum conductivity measurements varied only little among sites $(43-51 \mu \mathrm{S} / \mathrm{cm})$, while the minimum values ranged from $10-26 \mu \mathrm{S} / \mathrm{cm}$. The $\mathrm{pH}$ values varied in general more strongly, probably due to short-term changes in primary production and weather conditions, ranging from 4.9-8.4; in this physical parameter, both the highest average level and greatest stability occurred in a lotic habitat, the Miranda River. The same applies to dissolved oxygen, which was mostly higher and less variable in the river as compared to shallow lentic habitats (Lagoa Baiazinha, culture pond; Table 1).

Population structure: sex ratio, maximum body size, morphometric traits: In total, 2270 shrimps with sexable size were collected during this study, most of them from the Miranda River (1 068), followed by materials from the pond culture (688), and Lake Baiazinha (514 individuals; Table 1). In all samples and at all three sampling sites, consistently more females than males were collected. The sex ratio (males:females) observed at these sites was thus always strongly female-biased, with average values of $0.37,0.22$ and 0.59 , respectively (overall ratio:0.36).

As another consistent pattern, female shrimps reached generally a larger body size than males (overall maximum values in our materials: 65 vs. $58 \mathrm{~mm}$ total length, TL, respectively; Table 2). In general, the smallest 
TABLE 2

Maximum size (carapace length, CL; total length, TL) reached in Macrobrachium amazonicum populations living in estuarine and continental waters with lotic or lentic conditions

\begin{tabular}{|c|c|c|c|c|c|}
\hline & \multicolumn{4}{|c|}{ Maximum body size } & \multirow{3}{*}{ Reference } \\
\hline & \multicolumn{2}{|c|}{ Males } & \multicolumn{2}{|c|}{ Females } & \\
\hline & $\mathrm{TL}(\mathrm{mm})$ & $\mathrm{CL}(\mathrm{mm})$ & $\mathrm{TL}(\mathrm{mm})$ & $\mathrm{CL}(\mathrm{mm})$ & \\
\hline \multicolumn{6}{|l|}{ ESTUARINE WATERS } \\
\hline Amapá, Brazil & 140 & $28.9^{*}$ & 136 & $31.3^{*}$ & Vieira 2003 \\
\hline Ceará, Brazil & 100 & $20.4^{*}$ & 110 & $25.1 *$ & Guest 1979 \\
\hline Ceará, Brazil & 94 & $19.2^{*}$ & 92 & $20.6^{*}$ & Santos et al. 2006 \\
\hline Pará, Brazil & 144 & $29.8^{*}$ & 130 & $30.0^{*}$ & Silva 2002 \\
\hline Pará, Brazil & 132 & $27.2^{*}$ & & & Moraes-Riodades \& Valenti 2002 \\
\hline Pará, Brazil & 141 & $29.1 *$ & 109 & $24.8^{*}$ & Silva et al. 2007 \\
\hline Pará, Brazil & 160 & $33.2 *$ & 140 & $32.4 *$ & Moraes-Valenti \& Valenti 2010 \\
\hline Pará, Brazil & & & 106 & $24.1^{*}$ & Lucena-Fredou et al. 2010 \\
\hline \multicolumn{6}{|l|}{ CONTINENTAL WATERS } \\
\hline \multicolumn{6}{|c|}{ Amazon \& Orinoco, lotic habitats } \\
\hline Amazon River, Brazil & 98 & 16.5 & 94 & 19.4 & Kensley \& Walker 1982 \\
\hline Amazon River, Brazil & & & 89 & $20.0^{*}$ & Magalhães 1985 \\
\hline Amazon River, Brazil & 106 & 22.0 & & & Odinetz Collart \& Moreira 1993 \\
\hline Amazon River, Brazil & $93^{*}$ & 19.0 & $97^{*}$ & 22.0 & Odinetz Collart \& Magalhães 1994 \\
\hline Amazon River, Brazil & $122 *$ & 25.1 & $89^{*}$ & 20.0 & Porto 2004 \\
\hline Amazon River, Brazil & $70^{* *}$ & $10.8^{*}$ & 73 & $16.1 *$ & Farias 2009 \\
\hline Amazon River, Peru & 91 & $18.5^{*}$ & 95 & $21.4 *$ & García-Dávila \& Magalhães 2004 \\
\hline Tocantins River, Brazil & 105 & $21.5^{*}$ & 98 & $22.1 *$ & Flexa et al. 2005 \\
\hline Tocantins River, Brazil & $136^{*}$ & 28.0 & $114^{*}$ & 26.0 & Odinetz Collart \& Magalhães 1994 \\
\hline Tocantins River, Brazil & 132 & 28.0 & 126 & 23.0 & Odinetz Collart 1987 \\
\hline various Rivers, Colombia & 79 & 17.8 & 89 & 16.7 & Valencia \& Campos 2007 \\
\hline \multicolumn{6}{|c|}{ Amazon \& Orinoco, lentic habitats } \\
\hline Amazon lakes, Brazil & $84^{*}$ & 17.0 & $81^{*}$ & 18.0 & Odinetz Collart \& Magalhães 1994 \\
\hline Amazon lakes, Brazil & & & $93 *$ & 21.0 & Odinetz Collart 1991a \\
\hline Tucurui reservoir, Brazil & $89^{*}$ & 18.0 & $81^{*}$ & 18.0 & Odinetz Collart \& Magalhães 1994 \\
\hline Tucurui reservoir, Brazil & & & $65^{*}$ & 14.1 & Odinetz Collart 1991b \\
\hline Orinoco lakes, Venezuela & & & 72 & $15.8^{*}$ & Romero 1982 \\
\hline \multicolumn{6}{|l|}{ Paraná-Paraguay, lotic habitats } \\
\hline Rio Miranda, Pantanal & 58 & 11.1 & 60 & 11.2 & present study \\
\hline \multicolumn{6}{|l|}{ Paraná-Paraguay, lentic habitats } \\
\hline Lagoa Baiazinha, Pantanal & 56 & 10.9 & 65 & 13.7 & present study \\
\hline Pond culture, Pantanal & 47 & 9.1 & 51 & 11.3 & present study \\
\hline Tietê reservoir, S. Paulo, Brazil & $44^{*}$ & 8.5 & $54^{*}$ & 11.4 & Pantaleão et al. 2012 \\
\hline
\end{tabular}

$*=\mathbf{C L}$ or $\mathbf{T L}$ values estimated from regression equations (Fig. 2).

shrimps were collected from the artificial pond culture, whereas larger individuals occurred in natural habitats, Lagoa Baiazinha and Rio Miranda (Table 2). While only few male individuals reached a body size above $50 \mathrm{~mm}$ TL, numerous females were found also in the size class 50-60mm. Individuals with $\mathrm{TL}>60 \mathrm{~mm}$ occurred only exceptionally in females and never in males.

When TL was plotted against CL, a linear regression model described this morphometric relationship in both sexes consistently better 
than a non-linear (logarithmic, exponential or allometric) model. This indicates that the various body parts grow at similar rates, and morphometric proportions change only gradually throughout juvenile and adult growth (Fig. 2). However, when these linear regressions were statistically compared between males and females, a small but highly significant difference in the slope parameters was detected (Fig. 2C). A significantly steeper slope indicates that body parts other than the carapace tend to grow in males at a slightly faster rate than in females. As a consequence, our regressions imply that large males (e.g. at $\mathrm{TL}=60 \mathrm{~mm}$ ) show a somewhat smaller CL compared to females with an equally large TL (in this example, $\mathrm{CL}=11.9$ vs. $12.9 \mathrm{~mm}$, respectively).

When the proportion of CL:TL is compared between size classes and sexes, this morphometric quotient changes in both sexes throughout juvenile and adult growth, increasing from 0.16-0.17 (in females and males, respectively) at the smallest sexable size ( $\mathrm{TL}=20 \mathrm{~mm}$ ) to $0.20-0.21$ at maximum body size $(T L=60 \mathrm{~mm})$. In summary, measurements of CL (which are technically easier and much more precise than those of TL) can reliably be used for studies of shrimp growth, but sexrelated differences in body proportions should be considered.

Size-biomass relationships: When linear dimensions of body size (CL, TL) were plotted against biomass (measured here as fresh weight, FW), consistently an allometric growth pattern was obtained (TL-FW relationships shown as examples, Fig. 3). Again, statistical comparisons of slope parameters showed that these relationships varied significantly between males and females, with or without eggs, respectively (Fig. 3D). While practically no differences in FW occurred between small males and females $(<30 \mathrm{~mm} \mathrm{TL})$, larger individuals became increasingly dissimilar. When FW is compared between males and females (without eggs) at approximately maximum TL $(60 \mathrm{~mm})$, females show significantly higher FW than males. This indicates morphometric differences between sexes, confirming the appearance that males are more slender than females with equal TL. When ovigerous females are considered separately, one can see that the egg masses (included in female FW) further enhance their total biomass, so that their TL-FW relationship shows a significantly steeper slope compared to both males and non-ovigerous females (Fig. 3D).

Reproductive traits: The smallest sexable males observed in our materials had a CL of $2.5 \mathrm{~mm}$ and a TL of $19 \mathrm{~mm}$. This size was in our study therefore considered as the lower limit for safe sex identification, and it may be considered as minimum estimate of the "size at the onset of maturity" (SOM; Anger \& Moreira 1998) for males. For females, SOM is indicated by minimum body size of ovigerous individuals. In our materials, the smallest eggcarrying female had a TL of $29.8 \mathrm{~mm}$ (or $6 \mathrm{~mm}$ CL; Table 3).

Among the 603 male shrimps collected in our study, there was no indication whatsoever of an occurrence of different morphotypes. All males corresponded to the form "translucent claw" (TC; Moraes-Riodades \& Valenti 2004).

Fecundity, expressed as number of eggs carried per female, shows allometric relationships to linear dimensions of female body size (CL, TL), while it increases linearly with female FW (Fig. 4).

In ovigerous females isolated from the pond culture, an average of $186 \pm 74$ (range: 87-387) larvae per female was released, the largest hatch being produced by the largest individual $(\mathrm{TL}=53.7 \mathrm{~mm})$. From this experiment, fecundity can be quantified as number of larvae released per female, and statistical relationships to CL, TL or FW may be obtained. When the fecundity-FW regression obtained from these data is compared with the equivalent relationship between egg number and FW, a significantly weaker slope is calculated for larval numbers regressed on FW (Fig. 4D). The increasing gap between regression lines obtained for numbers of egg or larvae, respectively, in relation to FW represents egg losses, 
TABLE 3

Reproductive traits of Macrobrachium amazonicum populations living in estuarine and continental waters with lotic or lentic conditions

\begin{tabular}{|c|c|c|c|c|c|c|c|}
\hline & \multicolumn{4}{|c|}{ Minimum body size } & \multirow{3}{*}{$\begin{array}{c}\text { Maximum } \\
\text { Fecundity } \\
\text { (eggs) }\end{array}$} & \multirow{3}{*}{$\begin{array}{c}\text { Egg size } \\
(1 \times \mathrm{h}, \mathrm{mm})\end{array}$} & \multirow{3}{*}{ Reference } \\
\hline & \multicolumn{2}{|c|}{ Males } & \multicolumn{2}{|c|}{ Ovigerous females } & & & \\
\hline & $\begin{array}{c}\mathrm{TL} \\
(\mathrm{mm})\end{array}$ & $\begin{array}{c}\mathrm{CL} \\
(\mathrm{mm})\end{array}$ & $\begin{array}{c}\mathrm{TL} \\
(\mathrm{mm})\end{array}$ & $\begin{array}{c}\mathrm{CL} \\
(\mathrm{mm})\end{array}$ & & & \\
\hline \multicolumn{8}{|l|}{ ESTUARINE WATERS } \\
\hline Amapá, Brazil & 46 & 8.0 & 69 & $15.0^{*}$ & 4033 & & Vieira 2003 \\
\hline Ceará, Brazil & & & & & 2193 & & da Silva et al. 2004 \\
\hline Ceará, Brazil & & & 59 & $12.7^{*}$ & 2200 & $0.63 \times 0.85$ & Guest 1979 \\
\hline Ceará, Brazil & 39 & $7.5^{*}$ & & & & & Santos et al. 2006 \\
\hline Pernambuco, Brazil & & & 57 & 13.0 & 2673 & $0.57 \times 0.73$ & Vega Perez 1984 \\
\hline Pará, Brazil & & & 38 & $7.5^{*}$ & 1344 & & Lobão et al. 1986 \\
\hline Pará, Brazil & & & & & 6513 & 0.76 & Ribeiro 2003 \\
\hline Pará, Brazil & & & 52 & $10.9^{*}$ & 3375 & & Lucena-Fredou et al. 2010 \\
\hline Pará, Brazil & $57^{*}$ & 11.2 & & & & & Moraes-Riodades \& Valenti 2004 \\
\hline \multicolumn{8}{|l|}{ CONTINENTAL WATERS } \\
\hline \multicolumn{8}{|c|}{ Amazon \& Orinoco, lotic habitats } \\
\hline Amazon River, Brazil & 81 & 15.0 & 66 & 12.9 & 1277 & $0.50 \times 0.70$ & Kensley \& Walker 1982 \\
\hline Amazon River, Brazil & & & 49 & $10.2^{*}$ & 2259 & $0.77 \times 1.05$ & Magalhães 1985 \\
\hline Amazon River, Brazil & & & $36^{*}$ & 7.0 & 2165 & & Odinetz Collart 1991 \\
\hline Tocantins River, Brazil & 22 & 3.8 & & & & & Flexa et al. 2005 \\
\hline Tocantins River, Brazil & & & $44 *$ & 9.0 & 5706 & & Odinetz Collart \& Magalhães 1994 \\
\hline Tocantins River, Brazil & & & $36^{*}$ & 7.0 & 617 & & Odinetz Collart \& Magalhães 1994 \\
\hline Apure, Venezuela & & & & & 1000 & $0.83 \times 1.03$ & Gamba 1984 \\
\hline \multicolumn{8}{|c|}{ Amazon \& Orinoco, lentic habitats } \\
\hline Amazon lakes, Brazil & & & $48^{*}$ & 10.0 & 2850 & & Odinetz Collart \& Magalhães 1994 \\
\hline Pernambuco, Brazil & & & 57 & 12.7 & 2673 & $0.57 \times 0.73$ & Vega Perez 1984 \\
\hline Orinoco lakes, Venezuela & & & 41 & $8.2^{*}$ & 953 & $0.60 \times 1.00$ & Romero 1982 \\
\hline \multicolumn{8}{|c|}{ Paraná-Paraguay, lotic habitats } \\
\hline Rio Miranda, Pantanal & 22 & 4.1 & 34 & 6.7 & 479 & & present study \\
\hline \multicolumn{8}{|l|}{ Lentic } \\
\hline Lagoa Baiazinha, Pantanal & 19 & 2.5 & 43 & 7.6 & 676 & $0.57 \times 0.92$ & present study \\
\hline Pond culture, Pantanal & 21 & 4.1 & 30 & 6.0 & 485 & $0.53 \times 0.93$ & present study \\
\hline Goiás, Brazil & 14 & 2.7 & $33^{*}$ & 6.4 & 315 & $0.66 \times 0.83$ & Porto 1998 \\
\hline Tietê reservoir, SP, Brazil & $23^{*}$ & 4.0 & $29 *$ & 5.3 & & & Pantaleão et al. 2012 \\
\hline
\end{tabular}

Minimum body size (carapace length, CL; total length, TL) of males with appendix masculina and of ovigerous females, considered as estimates of size at the onset of maturity (SOM); egg size given as average larger and smaller diameter (1, h; where data are available). ${ }^{*}=\mathbf{C L}$ or $\mathbf{T L}$ values estimated from regression equations (Fig. 2).

which seem to gradually increase with increasing female size.

Throughout the period of embryonic development, the average egg volume increased from stage I to II by about $30 \%$, and it almost doubles during the final stage III, eventually reaching a 2.4-fold higher value than in the initial stage I (Table 4).

\section{DISCUSSION}

Our study provides preliminary data on the ecology and reproduction of shrimp populations (currently assigned to $M$. amazonicum) from the upper Paraná-Paraguay (or La Plata) basin. Since our data suggest both smallscale and short-term variability in physical 



Fig. 4. Power functions and linear regressions describing fecundity (number of eggs per female) in relation to carapace length (CL, graph A), total length (TL, graph B) and fresh weight (FW, graph C) in Macrobrachium amazonicum from the Pantanal (pooled data from three sampling sites); $\mathrm{r}^{2}$, coefficient of determination; $\mathrm{n}$, number of observations; $\mathrm{F}$ statistic and level of significance, P, for statistical comparisons between slopes (ANCOVA; graph D) indicate significant differences between linear FW-fecundity relationships in terms of numbers of eggs produced or larvae released, respectively.

TABLE 4

Macrobrachium amazonicum, egg size in three different stages of embryonic development (I-III)

\begin{tabular}{cccc} 
Stage & $\mathrm{h}$ & 1 & $\mathrm{~V}$ \\
I & $0.53 \pm 0.02(0.47-0.55)$ & $0.67 \pm 0.03(0.63-0.71)$ & $0.10 \pm 0.01(0.07-0.11)$ \\
II & $0.57 \pm 0.03(0.53-0.63)$ & $0.80 \pm 0.06(0.73-0.90)$ & $0.13 \pm 0.02(0.11-0.19)$ \\
III & $0.72 \pm 0.06(0.60-0.78)$ & $0.93 \pm 0.08(0.75-1.00)$ & $0.24 \pm 0.06(0.14-0.32)$ \\
\hline
\end{tabular}

Smaller and larger diameters (height, h; length, 1; in $\mathrm{mm})$, volume, V ( $\mathrm{mm}^{3}$, estimated from diameter assuming an ellipsoid form). Mean $\pm \mathrm{SD}(\mathrm{n}=12)$, range in parentheses.

conditions (temperature, conductivity, $\mathrm{pH}$, dissolved oxygen concentration), future studies should further analyze this variability as well as large-scale regional, seasonal and annual variations in the context of seasonal flood pulses and dry periods in relation to differences in the elevation and connectivity of different aquatic habitats (see Junk et al. 2011a, Nunes da Cunha \& Junk 2011b). In spite of its preliminary nature, however, our study has already shown several remarkable biological differences between populations living in the Pantanal and those from estuaries or from limnic inland waters of other drainage basins in Northern South America.

Although numerous significant differences among populations had previously been observed in morphological and morphometric 
traits (Porto 2004) as well as in molecular genetics (Bastos 2002), these variations have, so far, not been considered as sufficient to justify a taxonomic splitting of the M. amazonicum complex (Maciel \& Valenti 2009, Vergamini et al. 2011). In contrast, recent findings of developmental and physiological differences between shrimps from estuarine (Northern Brazilian) and limnic inland (Pantanal) waters, respectively, have been interpreted as indications of an at least incipient phylogenetic divergence between allopatric populations (Anger \& Hayd 2010, Charmantier \& Anger 2011, Urzúa \& Anger 2011).

One of the most striking differences between estuarine and land-locked inland populations, in general, is the capability of the latter to complete their life cycles in freshwater, while the former must "export" their larvae to waters with higher salt concentrations (for recent review, see Charmantier \& Anger 2011). Shrimps from the Pantanal show a significantly higher capacity of hyper-osmoregulation in freshwater than those from an estuarine population, but they have lost the presumably ancestral function of hypo-osmoregulation in seawater (Charmantier \& Anger 2011). These contrasting physiological traits are relevant in the context of evolutionary invasions of limnic environments by originally marine crustaceans, especially as they already appear in the earliest life-history stages, allowing for larval development in freshwater.

Likewise, also the present data corroborate the hypothesis that shrimps from the ParanáParaguay basin, which are currently assigned to $M$. amazonicum, may actually represent a separate, endemic species. One of the most striking differences was found in maximum body size. Adult shrimps reach in the Pantanal maximally only about one third to one half (males and females, respectively) of the size that is commonly observed in other drainage basins within the vast geographic distributional range of this taxon. Our data, obtained from $>2000$ individuals, correspond very well with those available from other regions within the same drainage basin, namely from Goiás
(Porto 1998) and a reservoir receiving water from the Rio Tietê, São Paulo state (Pantaleão et al. 2012). This suggests general similarity in life-history traits of shrimps living in various parts of the La Plata drainage system, implying similar patterns of difference from the remaining populations.

Smaller maximum body size in a pond culture compared to natural habitats (47 vs. $56-58 \mathrm{~mm}$ in males, $51 \mathrm{vs}$. $60-65 \mathrm{~mm}$ in females) indicate that high population densities as well as nutritional or other ecological factors may also affect the body size that can be reached in a population (Moraes-Valenti \& Valenti 2007, Moraes-Valenti et al. 2010). Size differences observed between cultured and natural populations in the Pantanal may be due either to lower growth rates or shorter life spans under mass culture conditions. However, these differences are very small compared to those among populations from different drainage basins. This suggests that striking interpopulational variations in maximum size, in particular in males, cannot be explained by phenotypic plasticity. Rather, they suggest particularly short longevity in Pantanal shrimps, especially in males, likely reflecting genetic drift or different selection pressures on life-history patterns (Graur 2001, Mousseau \& Olvido 2005).

As another consistent difference in population structure and reproductive traits, females reach in the Pantanal and in other regions of the La Plata basin a larger maximum body size than males, while the opposite pattern has typically been observed in other populations. This may be related to variation in another reproductive trait, namely the presence or absence of male morphotypes with differentially expressed major chelipeds. Male morphotypes appear to be completely absent in the region of the Paraná-Paraguay basin (present study, Porto 1998, Pantaleão et al. 2012), while they are common in other populations assigned to the same species (Moraes-Riodades \& Valenti 2004, Papa et al. 2004, da Silva et al. 2009). They occur also in some congeners, e.g. in $M$. rosenbergii de Man 1879 (Kuris et al. 1987) and M. vollenhovenii Herklots 1851 (Konan et 
al. 2010), while they are absent in other species, e.g. M. australiense Holthuis 1950 (Lee \& Fielder 1982) and M. ohione Smith 1874 (Bauer 2004). In species lacking male morphotypes, as in the shrimps from the Pantanal, females typically grow to larger maximum size than males (e.g. Truesdale \& Mermilliod 1979, Bauer \& Delahoussaye 2008).

Differences in growth and reproductive traits have significant implications for mating systems, which are generally considered as species-specific characteristics and barriers for gene flow (Bauer \& Abdalla 2001, Correa \& Thiel 2003, Bauer 2004, Bauer \& Thiel 2011). The occurrence of strong sexual dimorphism and, particularly in Macrobrachium spp., of male morphotypes with extremely large chelae is associated with mate-guarding behaviour (Barki et al. 1991a, b, Bauer 2004, MoraesRiodades \& Valenti 2004). Weakly expressed sexual dimorphism with smaller males, by contrast, is typically associated with indiscriminate mate selection and lacking investment in the defence of females as potential mating partners ("pure search" or "sneak mating" tactics; Wickler \& Seibt 1981, Laufer et al. 1994, Correa \& Thiel 2003, Bauer \& Abdalla 2001, Bauer 2004, Bauer \& Thiel 2011). Differential mating behaviours, with mate-guarding in estuarine M. amazonicum (originating from Pará, Brazil) and pure search in Pantanal shrimps, have consistently been observed also in long-term "common garden" laboratory cultures (Anger \& Hayd unpublished). In Pantanal shrimps, indiscriminate mating may favour a population structure with low proportions of males, i.e. lower sex ratios. Female-biased sex ratios were also observed in the Mississippi River system in Louisiana, with values close to 1 occurring only in the Atchafalaya River estuary during the breeding season, when females migrate downstream in order to release larvae (Bauer \& Delahoussaye 2008).

Sex ratios reported from natural populations of M. amazonicum are consistently below 1.0, indicating a general preponderance of females. In our materials, the overall ratio was 0.4 (varying from 0.2-0.6 among sampling sites), which falls within the range of 0.2-0.8 observed in various other populations assigned to M. amazonicum (Odinetz-Collart 1991, Vieira 2003, Flexa et al. 2005, Santos et al. 2006, Sampaio et al. 2007, Pantaleão et al. 2012). As the currently available data are too scarce to allow for safe conclusions, more field studies are necessary to analyze relationships between variations in sex ratio, mating systems, ecological conditions, and phylogenetic divergence.

Another difference between populations may be seen in the minimum sexable size of males (appearance of appendix masculina). In the Pantanal, males reached this reproductive stage at a smaller size compared to most other populations, especially to those from estuaries. The smallest identifiable males had in our materials a total length (TL) of $19 \mathrm{~mm}$, which is similar to the minimum values measured in the Rio Tietê (23mm; Pantaleão et al. 2012); an even smaller male size was observed only in Goiás (Porto 1998). Except for a single report of a similarly low value in a population outside the La Plata system (22mm; Rio Tocantins; Flexa et al. 2005), values provided in the literature are generally higher.

Similar to males, also female shrimps from the Pantanal seem to reach sexual maturity earlier than those from other drainage basins. The available data suggest that females in estuarine populations begin with egg laying mostly at $>50 \mathrm{~mm} \mathrm{TL}$, while generally smaller minimum values (down to $36 \mathrm{~mm}$ ) have been reported from limnic inland populations in the Amazon and Orinoco basins. The smallest ovigerous females found in our samples had a TL of $30 \mathrm{~mm}$, which is similar to minimum size observed in the Rio Tietê $(29 \mathrm{~mm}$; Pantaleão et al. 2012) and in Goiás (33mm; Porto 1998). All these values correspond to about one half of maximum female size reached in the same populations $(\mathrm{RSOM} \approx 50 \%$; Anger \& Moreira 1998).

In crustaceans with similar body forms, fecundity depends primarily on body size. It is therefore not surprising that egg numbers observed in small-sized Pantanal shrimps were generally far lower than the numbers reported 
for much larger shrimps from other populations. M. amazonicum from estuarine or Amazonian populations can reach about twice the maximum size observed in the Pantanal, while maximum fecundity differs by one order of magnitude (676 vs. 6513 eggs per female; cf. present study, Ribeiro 2003). Although fecundity increases as a non-linear (allometric) function of size, this difference remains strikingly large. When regressions describing fecundity of Pantanal shrimps in relation to female size or weight are extrapolated to maximum size occurring in other populations $(130 \mathrm{~mm})$, a theoretical maximum number of ca. 3000 egg is obtained. This is only about half the maximum fecundity found in estuarine populations (Ribeiro 2003), suggesting spatial limitations due to larger average egg size in shrimps from the Pantanal.

Significant differences between the numbers of eggs produced and those of larvae eventually released indicate egg losses, as observed also in other species of Macrobrachium (see Anger \& Moreira 1998, and references cited therein). These losses may in part be caused by parasites and bacterial or fungal infections (Kuris 1991). However, an increasing egg size occurring during the course of embryonic development may eventually also contribute to losses due to space constraints within the brooding chamber.

The available data on egg size in M. amazonicum from different populations are relatively scarce and also unreliable, because developmental changes occurring during embryogenesis have rarely been considered in the literature. A comparative study of different populations within the Amazon river system showed that egg size tends to increase with increasing distance from the sea (Odinetz-Collart \& Rabelo 1996). This is congruent with observations of larger average egg size in limnic inland waters of the Orinoco basin (Venezuela) compared to estuarine populations from Northern Brazil (Gamba 1984). Also, freshly hatched larvae released by females from the Pantanal show significantly larger size as well as higher dry mass and protein contents than those from an estuarine population, suggesting larger egg size in Pantanal shrimps (Urzúa \& Anger 2011). Comparative field studies of egg size measured in precisely defined developmental stages will be necessary to scrutinize such tendencies.

Smaller body size of Pantanal shrimps at the onset of maturity observed in both sexes, especially in males, implies a heterochronic shift in the development of reproductive systems. This predisplacement of maturation, due either to processes of neoteny or paedogenesis (for concepts and theory of heterochrony, see Brusca \& Brusca 1990, McKinney \& McNamara 2001), may compensate for presumably shorter longevity indicated by smaller maximum size (see above). As a consequence, life-time reproduction should be enhanced, and the generation turnover is accelerated, which suggests an r-selected life-history pattern (Reznick et al. 2002).

All characteristic reproductive traits of $M$. amazonicum from the Pantanal compared to those from other populations (e.g. differential maximum body size of males and females, the presence or absence of male morphotypes, typical mating behaviours, minimum sexable size, minimum size of ovigerous females, different larval size and biomass at hatching) persist, at least throughout several years and generations, also in large-scale aquaculture (Preto et al. 2010) and in small-scale cultures of both populations maintained under identical conditions in the laboratory (Anger \& Hayd 2009, Anger et al. 2009, Anger \& Hayd 2010, Charmantier \& Anger 2011, Urzúa \& Anger 2011). Longterm stability of differential reproductive or other biologically relevant traits in "common garden experiments" is generally considered as evidence for divergence of genetically fixed characters (Mousseau \& Olvido 2005).

Future comparative studies of reproductive and other life-history traits may show further characteristic differences between hydrographically and genetically isolated populations of $M$. amazonicum. While vicariant divergence between shrimps from the Pantanal and estuarine populations in Northern and Northeastern Brazil is obvious, the situation is not as 
clear in the Amazon, Orinoco and other large South American rivers, where geographical and genetic isolation is incomplete. If future studies can show phylogenetic divergence also between distant populations living in the same river system, e.g. in the upper and lower Amazon, such findings may provide interesting examples of parapatric speciation due to reduced gene flow over enormous distances (Ritchie 2001). Regardless of vicariant or parapatric mechanisms, the M. amazonicum complex will remain a highly interesting model for studies of phylogenetic divergence and speciation in the context of evolutionary invasions of limnic environments.

\section{ACKNOWLEDGMENTS}

This research was partially financed by CPP (Grant: 2008/CPP/2008), CAPES (Grant: 1154/10-9) and FUNDECT (Grants: 23/200.116/2008 and 23/200.174/2009), Brazil. The authors thank Dr. Celio Magalhães (INPA, Manaus) for the identification of shrimps, the CARCIPANTA collaborators J. Nakagaki, D. Pavei, J. Mussato, C. Lopes, L. Caballero, K. Vercezi, and L. Emiliano (Aquidauana) for their help during field and laboratory work, Beto Pellegrin (EMBRAPA Pantanal, CPAP) for producing the map, A. Urzúa (Helgoland) for help writing the Spanish Resumen, and Professor Ray Bauer (University of Louisiana, USA) for stimulating discussions and useful hints that helped to improve this paper.

\section{RESUMEN}

El camarón palaemónido Macrobrachium amazonicum muestra una distribución geográfica inusualmente grande (aprox. $4000 \mathrm{~km}$ de diámetro), vive en las zonas costeras, estuarios y hábitats interiores límnicos del alto Amazonas, Orinoco y las cuencas de La Plata. Esto plantea dudas sobre sí poblaciones alopátricas y ecológicamente diversas pertenecen a la misma especie. Mientras que los camarones de estuarios y de hábitats Amazónicos se han estudiado con gran detalle, se sabe muy poco acerca de las poblaciones holo-limnéticas del interior. En el presente estudio, los rasgos biológicos relacionados con el crecimiento (tamaño máximo del cuerpo, peso fresco, relaciones morfométricas) y la reproducción (proporción de sexos; ocurrencia de morfotipos masculinos; tamaño mínimo sexable; tamaño mínimo de las hembras ovígeras; fecundidad; tamaño del huevo), fueron estudiados en $M$. amazonicum recolectados en un estanque de cultivo y dos hábitats naturales de agua dulce (Río Miranda; Baiazinha Lagoa) en el Pantanal de Mato Grosso do Sul, Brasil. En total, 2270 camarones fueron examinados (603 machos, 1667 hembras, 157 de estas ovígeras). La proporción de sexos (machos:hembras) fue en todos los sitios de muestreo fuertemente sesgada por hembras, desde 0.2 hasta 0.6. El tamaño corporal máximo fue mayor en los hábitats naturales comparado con el estanque de cultivo, sugeriendo un crecimiento reducido o un lapso de vida más corto en condiciones artificiales de crianza masiva. La fecundidad máxima observada en nuestro material fue 676 huevos, alcanzado por la hembra de mayor tamaño (largo total, $\mathrm{LT}=65 \mathrm{~mm}$ ). Una diferencia significativa entre los parámetros de pendiente de regresiones lineales que describen la fecundidad, comparando el número de huevos puestos o de larvas liberadas, en relación con el peso de la hembra, indican pérdida de huevos. Esto puede ser debido a un aumento de 2.4 veces en el volumen del huevo que ocurre durante el desarrollo embrionario, mientras que el espacio disponible bajo el abdomen sigue siendo limitado. Relaciones de tamaño-peso diferían significativamente entre machos y hembras, lo que indica diferencias morfométricas sexoespecíficas. Los machos parecen tener una forma de cuerpo más delgado que las hembras, alcanzando por lo tanto el peso más bajo en la igualdad de LT. Cuando los rasgos reproductivos y morfométricos son comparados con datos de la literatura de poblaciones estuarinas y poblaciones del interior que viven en el Amazonas y en los llanos del Orinoco, los camarones del Pantanal muestran peculiaridades diferentes: (1) el tamaño máximo del cuerpo es mucho más pequeño, lo que sugiere menor longevidad; (2) las hembras son más grandes que los machos; (3) diferentes morfotipos masculinos están ausentes; (4) el tamaño mínimo sexable y (5) el tamaño mínimo de hembras ovígeras son más pequeños. Estas características sugieren un cambio heterocrónico (pre-desplazamiento) de la maduración sexual y la selección-r. En resumen, nuestros datos muestran diferencias biológicamente relevantes en los rasgos de la historia de vida de los camarones del Pantanal comparados con M. amazonicum en otras regiones. Todas estas diferencias persisten también en cultivos a largo plazo mantenidos bajo condiciones constantes. En conjunto, nuestros datos apoyan la hipótesis que $M$. amazonicum en la desembocadura de la cuenca Paraná-Paraguay ha divergido filogenéticamente de poblaciones alopátricas que están hidrológicamente separadas por cuencas continentales, lo que implica al menos una incipiente especiación vicariante. 
Palabras clave: Caridea, camarones de agua dulce, crecimiento, reproducción, fecundidad, historia de vida.

\section{REFERENCES}

Albert, J.S., P. Petry \& R.E. Reis. 2011. Major Biogeographic and Phylogenetic Patterns, p. 21-57. In J.S. Albert \& R.E. Reis (eds.). Historical Biogeography of Neotropical Freshwater Fishes. The Regents of the University of California, Berkeley, California, USA.

Anger, K. \& L. Hayd. 2009. From lecithotrophy to planktotrophy: ontogeny of larval feeding in the Amazon River prawn Macrobrachium amazonicum. Aquat. Biol. 7: 19-30.

Anger, K. \& L. Hayd. 2010. Feeding and growth in early larval shrimp Macrobrachium amazonicum from the Pantanal, southwestern Brazil. Aquat. Biol. 9: 251-261.

Anger, K., L. Hayd, J. Knott \& U. Nettelmann. 2009. Patterns of larval growth and chemical composition in the Amazon River prawn, Macrobrachium amazonicum. Aquaculture 287: 341-348.

Anger, K. \& G.S. Moreira. 1998. Morphometric and reproductive traits of tropical Caridean shrimps. J. Crust. Biol. 18: 823-838.

Barki, A., I. Karplus \& M. Goren. 1991a. The agonistic behaviour of the three male morphotypes of the freshwater prawn Macrobrachium rosenbergii (Crustacea, Palaemonidae). Behavior 116: 252-277.

Barki, A., I. Karplus \& M. Goren. 1991b. Morphotype related dominance hierarchies in males of Macrobrachium rosenbergii (Crustacea, Palaemonidae). Behavior 117: 145-160.

Bastos, S.N. 2002. Caracterização molecular e biologia reprodutiva de Macrobrachium amazonicum (Crustacea, Decapoda, Palaemonidae). Master Thesis, Universidade Federal do Pará, Bragança, Pará, Brazil.

Bauer, R.T. 2004. Remarkable Shrimps: Adaptations and Natural History of the Carideans. University of Oklahoma, Norman, Oklahoma, USA.

Bauer, R.T. \& J.H. Abdalla. 2001. Male mating tactics in the shrimp Palaemonetes pugio (Decapoda, Caridea): precopulatory mate guarding vs. pure searching. Ethology 107: 185-199.

Bauer, R.T. \& J. Delahoussaye. 2008. Life history migrations of the amphidromous river shrimp Macrobrachium ohione from a continental large river system. J. Crust. Biol. 28: 622-632.

Bauer, R.T. \& M. Thiel. 2011. First description of a puresearch mating system and protandry in the shrimp Rhynchocinetes uritai (Decapoda: Caridea). J. Crust. Biol. 31: 286-295.
Briggs, R.P., M.J. Armstrong, M. Dickey-Collas, M. Allen, N. McQuaid \& J. Whitmore. 2002. The application of fecundity estimates to determine the spawning stock biomass of Irish Sea Nephrops norvegicus (L.) using the annual larval production method. ICES J. Mar. Sci. 59: 109-119.

Brown, J.H., M.B. New \& D. Ismael. 2010. Biology, p. 18-39. In M.B. New, W.C. Valenti, J.H. Tidwell, L.R. D'Abramo \& M.N. Kutty (eds.). Freshwater prawns: biology and farming. Wiley, Chichester, United Kingdom.

Brusca, R.C. \& G.J. Brusca. 1990. Invertebrates. Sinauer, Sunderland, Massachusetts, USA.

Buckup, P.A. 2011. The Eastern Brazilian Shield, p. 203210. In J.S. Albert \& R.E. Reis (eds.). Historical Biogeography of Neotropical Freshwater Fishes. The Regents of the University of California, Berkeley, California, USA.

Carvalho, T.P. \& J.S. Albert. 2011. The Amazon-Paraguay Divide, p. 193-202. In J.S. Albert \& R.E. Reis (eds.). Historical Biogeography of Neotropical Freshwater Fishes. University of California, Berkeley, California, USA.

Castillo, J., N. Eslava \& L.W. González. 2011. Crecimiento del cangrejo Callinectes danae (Decapoda: Portunidae) de la Isla de Margarita, Venezuela. Rev. Biol. Trop. 59: 1525-1535.

Charmantier, G. \& K. Anger. 2011. Ontogeny of osmoregulatory patterns in the South American shrimp Macrobrachium amazonicum: Loss of hypo-regulation in a land-locked population indicates phylogenetic separation from estuarine ancestors. J. Exp. Mar. Biol. Ecol. 396: 89-98.

Correa, C. \& M. Thiel. 2003. Mating systems in caridean shrimp (Decapoda: Caridea) and their evolutionary consequences for sexual dimorphism and reproductive biology. Rev. Chil. Hist. Nat. 76: 187-203.

da Silva, G.M.F., M.A.P. Ferreira, E.I.C.F.V. Ledebur \& R. Martins da Rocha. 2009. Gonadal structure analysis of Macrobrachium amazonicum (Heller, 1862) from a wild population: a new insight into the morphotype characterization. Aquaculture. Res. 40: 798-803.

de Grave, S. \& C.H.J.M. Fransen. 2011. Carideorum Catalogus: The recent species of the Dendrobranchiate, Stenopodidean, Procarididean and Caridean shrimps (Crustacea: Decapoda). Zool. Medel. Leiden 85: 195-588.

de Grave, S., N.D. Pentcheff, S.T. Ahyong, T.Y. Chan, K.A. Crandall, P.C. Dworschak, D.L. Felder, R.M. Feldmann, C. Fransen, L.Y.D. Goulding, R. Lemaitre, M.E.Y. Low, J.W. Martin, P.K.L. Ng, C.E. Schweitzer, S.H. Tan, D. Tshudy \& R. Wetzer. 2009. A classification of living and fossil genera of decapod crustaceans. Raffles B. Zool. Suppl. 21: 1-109. 
Depaula, J.E., C.D. Conceição \& M. Macedo. 1995. Information about the Pantanal-Passo-da-Lontra. Pesqui. Agropecu. Bras. 30: 583-594.

Farias, A.M. 2009. Crescimento relativo do camarão Macrobrachium amazonicum (Heller, 1862) (Crustacea, Decapoda, Palaemonidae), capturados próximo ao município de Itacoatiara (AM), Brasil. Anais do IX Congresso de Ecologia do Brasil, 13 a 17 de Setembro de 2009, São Lourenço - MG, Brazil: 1-3.

Flexa, C.E., K.C.D.A. Silva \& I.H.A. Cintra. 2005. Morfometria do camarão-canela, Macrobrachium amazonicum (Heller, 1862), no município de Cametá - Pará. Bol. Téc. Cient. CEPNOR, Belém, Pará, Brazil 5: 41-54.

Freire, C.A., F. Cavassin, E.N. Rodrigues, A.H. Torres \& J.C. McNamara. 2003. Adaptive patterns of osmotic and ionic regulation, and the invasion of fresh water by the palaemonid shrimps. Comp. Biochem. Phys. A 136: 771-778.

Gamba, A.L. 1984. Different egg-associated and larval development characteristics of Macrobrachium jelskii and Macrobrachium amazonicum (Arthropoda: Crustacea) in a Venezuelan continental lagoon. Int. J. Inver. Rep. Dev. 7: 135-142.

García-Dávila, C.R. \& C. Magalhães. 2004. Revisão taxonômica dos camarões de água doce (Crustacea: Decapoda: Palaemonidae, Sergestidae) da Amazônia Peruana. Acta Amazonica 33: 663-686.

Gomes Corrêa, M.M. 1977. Palemonídeos do Brasil (Crustacea - Decapoda - Natantia). Master Thesis, Universidade Federal de Rio de Janeiro, Rio de Janeiro, Brazil.

Graur, D. 2001. Mutational Change in Evolution. In Encyclopedia of Life Sciences (ELS). Wiley, Chichester, United Kingdom.

Guest, W.C. 1979. Laboratory life history of the palaemonid shrimp Macrobrachium amazonicum (Heller) (Decapoda, Palaemonidae). Crustaceana 37: 141-152.

Hartnoll, R.G. 1982. Growth, p. 111-196. In L.G. Abele (ed.). Embryology, Morphology and Genetics. Academic, New York, USA.

Hayd, L.A. \& J.M. Nakagaki. 2002. Os camarões de água doce (Palaemonidae) e a coleta de iscas no Rio Miranda, Pantanal de Miranda. Rev. Pantaneira 4 $37-50$.

Heckman, C.W. 1998. The Pantanal of Poconé. Biota and Ecology in the Northern Section of the World's Largest Pristine Wetland. Kluwer, Dordrecht, The Netherlands.

Holthuis, L.B. 1952. A general revision of the Palaemonidae (Crustacea, Decapoda, Natantia) of the Americas. II. The subfamily Palaemoninae. Allan Hancock Found. Publ. Occ. Pap. 12: 1-396.
Iriondo, M.H., J.C. Paggi \& M.J. Parma. 2007. The Middle Paraná River: Limnology of a Subtropical Wetland. Springer, Heidelberg, Germany.

Ismael, D. \& M.B. New. 2000. Biology, p. 18-40. In M.B. New \& W.C. Valenti (eds.). Freshwater Prawn Culture. Blackwell, Oxford, United Kingdom.

Ituarte, R.B., E.D. Spivak \& K. Anger. 2005. Effects of salinity on embryonic development of Palaemonetes argentinus (Crustacea: Decapoda: Palaemonidae) cultured in vitro. Invertebr. Reprod. Dev. 47: 213-223.

Ituarte, R.B., E.D. Spivak \& K. Anger. 2007. Intraspecific variability in life-history traits of a freshwater shrimp, Palaemonetes argentinus. Ann. Limnol. 43: 293-302.

Jalihal, D.R., K.N. Sankolli \& S. Shenoy. 1993. Evolution of larval developmental patterns and the process of freshwaterization in the prawn genus Macrobrachium Bate, 1868 (Decapoda, Palaemonidae). Crustaceana 65: 365-376.

Junk, W.J., C. Nunes da Cunha, C.J. Silva \& K.M. Wantzen. 2011a. The Pantanal: A large South American wetland and its position in limnological theory, p. 23-44. In W.J. Junk, C.J. Silva \& C. Nunes da Cunha (eds.). The Pantanal: Ecology, biodiversity and sustainable management of a large neotropical seasonal wetland. Pensoft, Sofia, Bulgaria.

Junk, W.J., C.J. Silva \& C. Nunes da Cunha. 2011b. The Pantanal: Ecology, biodiversity and sustainable management of a large neotropical seasonal wetland. Pensoft, Sofia, Bulgaria.

Kensley, B. \& I. Walker. 1982. Palaemonid shrimps from the Amazon basin (Crustacea: Decapoda: Natantia). Smithsonian Contrib. Zool. 362: 1-28.

Konan, K.M., A.B. Adepo-Gourene, A. Ouattara, W.D. Nyingy \& G. Gourene. 2010. Morphometric variation among male populations of freshwater shrimp Macrobrachium vollenhovenii Herklots, 1851 from Côte d'Ivoire Rivers. Fish. Res. 103: 1-8.

Köppen, W. 1936. Das geographische System der Klimate, p. 1-44. In W.A.G. Köppen (ed.). Handbuch der Klimatologie. Borntraeger, Stuttgart, Germany.

Kuris, A.M. 1991. A review of patterns and causes of crustacean brood mortality, p. 117-141. In A. Wenner \& A. Kuris (eds.). Crustacean Egg Production, Balkema, Rotterdam, The Netherlands.

Kuris, A.M., Z. Raanan, A. Sagi \& D. Cohen. 1987. Morphotypic differentiation of male Malaysian giant prawns, Macrobrachium rosenbergii. J. Crust. Biol. 7: 219-237.

Laufer, H., A. Sagi \& J.S.B. Ahl. 1994. Alternate mating strategies of polymorphic males of Libinia emarginata appear to depend on methyl farnesoate. Invert. Reprod. Dev. 26: 41-44. 
Lee, C.L. \& D.R. Fielder. 1982. Maintenance and reproductive behavior in the freshwater prawn Macrobrachium australience Holthuis (Crustacea: Decapoda: Palaemonidae). Austr. J. Mar. Freshwat. Res. 33: 629-646.

Lobão, V.L., N.E.T. Rojas \& W.C. Valenti. 1986. Fecundidade e fertilidade de Macrobrachium amazonicum (Heller, 1862) (Crustacea, Decapoda) em laboratório. B. Inst. Pesca 13: 15-20.

Lucena-Fredou, F., J.S. Rosa, M.C.N. Silva \& E.F. Azevedo. 2010. Population dynamics of the river prawn, Macrobrachium amazonicum (Heller, 1862) (Decapoda, Palaemonidae) on Combu island (Amazon estuary). Crustaceana 83: 277-290.

Maciel, C.R. \& W.C. Valenti. 2009. Biology, fisheries, and aquaculture of the Amazon river prawn Macrobrachium amazonicum: a review. Nauplius 17: 61-79.

Magalhães, C. 1985. Desenvolvimento larval obtido em laboratório de palaemonídeos da região Amazonica. I. Macrobrachium amazonicum (Heller, 1862) (Crustacea, Decapoda). Amazoniana 9: 247-274.

McKinney, M.L. \& K.J. McNamara. 1991. Heterochrony - The Evolution of Ontogeny. Plenum, New York, USA.

Mejía-Ortíz, L.M. \& M. López Mejía. 2011. Freshwater prawns of the genus Macrobrachium (Decapoda, Palaemonidae) with abbreviated development from the Papaloapan River Basin, Veracruz, Mexico: Distribution and New Species. Crustaceana 84: 949-973.

Melo, G.A.S. 2003. Manual de Identificação dos Crustacea Decapoda de Água Doce do Brasil. Edições Loyola: Centro Universitário São Camilo: Museu de Zoologia, Universidade de São Paulo, São Paulo, Brazil.

Mendes, C.A.B., S.A. Grehs, M.C.B. Pereira, S.R. Barreto, M. Becker, M.B.R. Lange \& F.A. Dias. 2004. Bacia Hidrográfica do Rio Miranda. Estado da Arte. UCDB. Campo Grande, Mato Grosso do Sul, Brazil.

Moraes-Riodades, P.M.C. \& W.C. Valenti. 2004. Morphotypes in male Amazon river prawns, Macrobrachium amazonicum. Aquaculture 236: 297-307.

Moraes-Valenti, P. \& W.C. Valenti. 2010. Culture of the Amazon River Prawn Macrobrachium amazonicum, p. 485-501. In M.B. New, W.C. Valenti, J.H. Tidwell, L.R. D'Abramo \& M.N. Kutty (eds.). Freshwater prawns: biology and farming. Wiley, Chichester, United Kingdom.

Moraes-Valenti, P.M.C. \& W.C. Valenti. 2007. Effect of intensification on grow-out of the Amazon River Prawn Macrobrachium amazonicum. J. World Aquaculture Soc. 38: 516-526.

Moraes-Valenti, P., P.A. De Morais, B.D. Preto \& W.C. Valenti. 2010. Effect of density on population development in the Amazon river prawn Macrobrachium amazonicum. Aquat. Biol. 9: 291-301.
Mousseau, T.A. \& A.E. Olvido. 2005. Geographical Variation, p.1-7. In Encyclopedia of Life Sciences (ELS). Wiley, Chichester, United Kingdom.

Nunes da Cunha, C. \& W.J. Junk. 2011a. Landscape units of the Pantanal: structure, function, and human use, p. 301-326. In W.J. Junk, C.J. Silva, C. Nunes da Cunha \& K.M. Wantzen (eds.). The Pantanal: Ecology, biodiversity and sustainable management of a large neotropical seasonal wetland. Pensoft, Sofia, Bulgaria.

Nunes da Cunha, C. \& W.J. Junk. 2011b. A preliminary classification of habitats of the Pantanal of Mato Grosso and Mato Grosso do Sul, and its relation to national and international wetland classification systems, p. 127-141. In W.J. Junk, C.J. Silva, C. Nunes da Cunha \& K.M. Wantzen (eds.). The Pantanal: Ecology, biodiversity and sustainable management of a large neotropical seasonal wetland. Pensoft, Sofia, Bulgaria.

Odinetz-Collart, O. 1991. Stratégie de reproduction de Macrobrachium amazonicum en Amazonie Centrale (Decapoda, Caridea, Palaemonidae). Crustaceana 61: 253-270.

Odinetz-Collart, O. \& H. Rabelo. 1996. Variation in egg size of the fresh-water prawn Macrobrachium amazonicum (Decapoda: Palaemonidae). J. Crust. Biol. 16: 684-688.

Pantaleão, J.A.F., G.L. Hirose \& R.C. da Costa. 2012. Relative growth, morphological sexual maturity, and size of Macrobrachium amazonicum (Heller 1862) (Crustacea, Decapoda, Palaemonidae) in a population with an entirely freshwater life cycle. Inver. Rep. Dev. 56: (180-190).

Papa, L.P., I.B.F. Vicentini, K. Ribeiro, C.A. Vicentini \& L.E. Pezzato. 2004. Diferenciação morfotípica de machos do camarão de água doce Macrobrachium amazonicum a partir da análise do hepatopâncreas e do sistema reprodutor. Acta. Sci. Anim. Sci. 26: 463-467.

Peel, M.C., B.L. Finlayson \& T.A. McMahon. 2007. Updated world map of the Köppen-Geiger climate classification. Hydrol. Earth Syst. Sci. 11: 1633-1644.

Pileggi, L.G. \& F.L. Mantelatto. 2010. Molecular phylogeny of the freshwater prawn genus Macrobrachium (Decapoda, Palaemonidae), with emphasis on the relationships among selected American species. Inverteb. System. 24: 194-208.

Pivari, M.O., V.J. Pott \& A. Pott. 2008. Aquatic macrophytes of floating mats ("baceiros") in the Abobral and Miranda Pantanal wetlands, Mato Grosso do Sul state, Brazil. Acta Botan. Bras. 22: 563-571.

Porto, L.A.C. 1998. Estrutura populacional e biologia reprodutiva de Macrobrachium amazonicum (Heller, 1862) (Crustacea, Decapoda, Palaemonidae), na bacia hidrográfica do Rio Meia Ponte, Bela Vista de Goiás, GO, Brasil. Master Thesis, Universidade de São Paulo, São Paulo, Brazil. 
Porto, L.A.C. 2004. Estudos morfológicos em populações do complexo Macrobrachium amazonicum (Heller, 1862) (Crustacea, Decapoda, Palaemonidae) em diferentes bacias hidrográficas brasileiras. Ph.D. Thesis, Universidade de São Paulo, São Paulo, Brazil.

Preto, B.L., J.M. Kimpara, P. Moraes-Valenti \& W.C. Valenti. 2010. Population structure of pond-raised Macrobrachium amazonicum with different stocking and harvesting strategies. Aquaculture 307: 206-211.

Reznick, D., M.J. Bryant \& F. Bashey. 2002. r- and $\mathrm{K}$-selection revisited: the role of population regulation in life-history evolution. Ecology 83: 1509-1520.

Resende, E.K., R.A.C. Pereira, V.L.L. Almeida \& A.G. Silva. 2000. Peixes onívoros da planície inundável do rio Miranda, Pantanal, Mato Grosso do Sul, Brasil. Embrapa Pantanal. Bol. Pesq. 16: 1-44.

Resende, E.K., R.A.C. Pereira, V.F. Sório \& E.M. Galvão. 2006. Biologia da tuvira, Gymnotus cf. carapo (Pisces, Gymnotidae) no baixo Rio Negro, Pantanal, Mato Grosso do Sul, Brasil. Embrapa Pantanal. Bol. Pesq. Desenv. 67: 1-42.

Ribeiro, K. 2003. Efeito dos ácidos graxos poliinsaturados sobre o desempenho reprodutivo de fêmeas de Macrobrachium amazonicum (Heller, 1862). Master Thesis, Universidade Estadual Paulista, Jaboticabal, São Paulo, Brazil

Ritchie, M.G. 2001. Speciation: Sympatric and Parapatric, p. 1-6. In Encyclopedia of Life Sciences (ELS). Wiley, Chichester, United Kingdom.

Romero, M.E. 1982. Preliminary observations on potential of culture of Macrobrachium amazonicum in Venezuela, p. 411-416. In M.B. New (ed.). Giant prawn farming. Elsevier, Amsterdam, The Netherlands.

Sampaio, C.M.S., R. Silva, J. Santos \& S.P. Sales. 2007. Reproductive cycle of Macrobrachium amazonicum females (Crustacea, Palaemonidae). Braz. J. Biol. 67: 551-559.

Santos, J.A., C.M.S. Sampaio \& A.A. Soares Filho. 2006. Male population structure of the Amazon river prawn (Macrobrachium amazonicum) in a natural environment. Nauplius 14: 55-63.

Soares, J.J. \& A.K.M. Oliveira. 2009. O paratudal do Pantanal de Miranda, Corumbá-MS, Brasil. Rev. Árvore 33: 339-347.

Sokal, R.R. \& F.J. Rohlf. 1995. Biometry. The Principles and Practice of Statistics in Biological Research. Freeman, San Francisco, California, USA.
Somers, K.M. 1991. Characterizing size-specific fecundity in crustaceans, p. 357-378. In A. Wenner \& A. Kuris (eds.). Crustacean Egg Production. Balkema, Rotterdam, The Netherlands.

Suarez, Y.R., M. Junior \& A. Cattela. 2004. Factors regulating diversity and abundance of fish communities in Pantanal lagoons, Brazil. Fish. Manage. Ecol. 11: 45-50.

Swarts, F.A.E. 2000. The Pantanal. Understanding and Preserving the World's Larges Wetland. Paragon House, St. Paul, Minnesota, USA.

Tondato, K.K., L.A.F. Mateus \& S.R. Ziober. 2010. Spatial and temporal distribution of fish larvae in marginal lagoons of Pantanal, Mato Grosso State, Brazil. Neotrop. Ichtyol. 1-11.

Truesdale, F.M. \& W.J. Mermilliod. 1979. The river shrimp Macrobrachium ohione (Smith) (Decapoda, Palaemonidae) - its abundance, reproduction, and growth in the Atchafalaya River basin of Louisiana, USA. Crustaceana 36: 61-73.

Urzúa, Á. \& K. Anger. 2011. Larval biomass and chemical composition at hatching in two geographically isolated clades of the shrimp Macrobrachium amazonicum: intra or interspecific variation? Int. J. Invertebr. Reprod. Dev. 55: 236-246.

Valencia, D.M. \& M.R. Campos. 2007. Freshwater prawns of the genus Macrobrachium Bate, 1868 (Crustacea: Decapoda: Palaemonidae) of Colombia. Zootaxa 1456: 1-44.

Vergamini, F.G., L.G. Pileggi \& F.L. Mantelatto. 2011. Genetic variability of the Amazon river prawn Macrobrachium amazonicum (Decapoda, Caridea, Palaemonidae). Contrib. Zool. 80: 67-83.

Vieira, I.M. 2003. Bioecologia e pesca do camarão, Macrobrachium amazonicum (Heller, 1862) no baixo Rio Amazonas - AP. Master Thesis, Universidade de Brasília, DF, Brazil.

Wantzen, K.M., W.J. Junk \& K.O. Rothhaupt. 2008. An extension of the floodpulse concept (FPC) for lakes. Hydrobiologia 613: 151-170.

Wickler, W. \& U. Seibt. 1981. Monogamy in Crustacea and man. Z. Tierpsychol. 57: 215-234.

Willink, P., B. Chernoff, L.E. Alonso, J. Montambault \& R. Lourival. 2000. A biological assessment of the aquatic ecosystems of the Pantanal, Mato Grosso do Sul, Brazil. Conservation International Washington, D.C., USA. 
